\title{
Review
}

\section{Glucagon like peptide 1 receptor agonists: a therapy for diabetes management}

\author{
Agonistas del receptor péptido 1 similar al glucagón: una
} terapia para el control de la diabetes

\author{
Natalia Andrea Rojas-Henao' ${ }^{1}$ CvLAC, EKkyn Johan Granados-Vega' ${ }^{1}$ CvLAC
}

Date correspondence:

Received: September 20, 2016.

Revised: November 2, 2017.

Accepted: November 16, 2017.

How to cite:

Rojas-Henao NA, Granados-Vega

EJ. Glucagon-like peptide 1

receptor agonists: a therapy for

the control of diabetes. Rev CES

Med 2018; 32 (1): 23-30.

Open access

(C) Derecho de autor

Licencia creative commons

Ética de publicaciones

Revisión por pares

Gestión por Open Journal System

DOI: http://dx.doi.org/10.21615/

cesmedicina.32.1.3

ISSN 0120-8705

e-ISSN 2215-9177

About the authors:

1.Pharmaceutical Chemistry, Diabetes Group, Hospital Pablo Tobón Uribe- Universidad de Antioquia.

Comparte

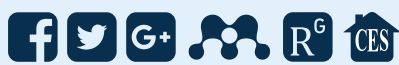

\begin{abstract}
Introduction: Glucagon-like peptide 1 agonists inhibit glucose-dependent glucagon secretion, decrease gastric emptying and appetite through neural mechanisms, contribute to glucose regulation and show reduction in glycated hemoglobin A. Methods: A bibliographic search was made on Medli$n e^{\circledR}$ about pharmacology of the agonist glucagon-like peptide-1 receptor , Liraglutide, Lixisenatide, Albiglutide, Exenatide, Exenatide with long-acting release. Results: The GLP1 receptor agonist are agents involved with glycemic balance, weight loss induction and are associated with lower risk of hypoglycemia. They have shown efficacy in the treatment of hypoglycemia in patients with type-2 diabetes. Conclusions: GLP1 receptor agonist are part of the therapies for diabetes that have shown benefits in metabolic control, effectiveness in weight reduction and changes in glycated hemoglobin. More studies are needed to evaluate its long-term safety.
\end{abstract}

Keywords: Diabetes Mellitus, Type 2; Glucagon-like peptide-1, Hypoglycemia, Hemoglobin A, glycosylated.

\section{Resumen}

Introducción: los agonistas del péptido 1 similar al glucagón inhiben la secreción del glucagón dependiente de glucosa, también disminuyen el vaciamiento gástrico y el apetito a través de mecanismos neurales contribuyen a la regulación de la glucosa y muestran reducción en la hemoglobina A glicada. Métodos: búsqueda bibliográfica en Medline sobre la farmacología de los agonistas del receptor del péptido 1 similar al glucagón: liraglutide, lixisenatide, albiglutide, exenatide, exenatide con liberación de acción prolongada. Resultados: los agonistas del receptor del péptido 1 similar al glucagón son agentes involucrados con el equilibrio glucémico, inducen pérdida de peso, se asocian a un menor riesgo de hipoglucemias y han mostrado eficacia en el tratamiento de la hiperglucemia en pacientes con diabetes tipo 2. Conclusiones: los agonistas del receptor del péptido 1 similar al glucagón forman parte de las terapias para la diabetes que han mostrado beneficios en el control metabólico, efectividad en la reducción de peso y cambios en la hemoglobina A glicosilada. Aún faltan estudios que evalúen su seguridad a largo plazo.

Palabras clave: Diabetes mellitus tipo 2; Péptido 1 similar al glucagón; Hipoglucemia; Hemoglobina A glicosilada. 
Enero - Abril 2018 - Pág 24

2. Clinical Research at Hospital Pablo Tobon Uribe, Prevention and Promotion Group Pharmaceutical in Universidad de Antioquia.
GLP-1 inhibits glucose-dependent glucagon secretion, decreases emptying gastric, reduces food intake and contributes to the regulation of glucose and satiety through neural mechanisms.

\section{Introduction}

Diabetes mellitus type 2 is currently a public health problem, its incidence and prevalence are increasing around the world hand in hand with obesity, especially in developing countries. Diabetes and obesity are components of the metabolic syndrome, its impact on health is substantial and include long-term complications such as cardiovascular-cerebrovascular events, renal disease and reduced expectancy and quality of life (1).

The pathophysiology includes multiple alterations and one of them is the attenuation of incretin effect that is accompanied by inappropriate levels of glucagon which contributes to chronic hyperglycemia with two different incretins: the insulinotropic polypeptide glucose-dependent (GIP) and glucagon-like peptide 1 (GLP-1), strongly involved with the glycemic balance (2).

GIP is synthesized in the duodenum and jejunum in K cells, while GLP-1 is synthesized in the L cells, in the distal ileum and the colon. After food intake, GIP and GLP-1 values increase; however, these post-prandial concentrations rapidly diminished by the enzymatic inactivation of dipeptidyl peptidase 4 (DPP4). Fasting, GLP-1 levels are between 5-10 pmol / L, reaching levels of 5-50 pmol / L during food intake (3).

Intact plasma GLP-1 and biologically active represents only $10-20 \%$ of the total (9). for this reason different strategies have been developed to overcome the barrier that involves the instantaneous inactivation of GLP-1 by the DPP-4 enzyme, as the DPP-4 inhibitors and GLP-1 receptor agonists (AR-GLP1) (4).

GLP-1 receptor is expressed in alpha islets, beta cells and peripheral tissues, including central and peripheral nervous system, heart, kidneys, lungs and gastrointestinal tract. According to its distribution and expression, GLP-1 inhibits glucose-dependent glucagon secretion, decreases emptying gastric, reduces food intake and contributes to the regulation of glucose and satiety through neural mechanisms (ㄷ).

The AR-GLP-1 are part of the glucose reducing agents associated with reduction of body weight, in addition to inhibitors of the sodium-glucose cotransporter type 2; its therapy is based on the administration of doses applied by subcutaneous injection, among which are: exenatide, LAR exenatide, lixisenatide, liraglutide and albiglutide (ㅇ).

The objective of this review is to describe the main characteristics of agonists of GLP-1 receptor in diabetes, weight control and adverse effects profile.

\section{Methodology}

A review was made about the pharmacology of peptide receptor agonists 1 like glucagon liraglutide, lixisenatide, albiglutide, exenatide, exenatide LAR in humans, in PubMed / Medline, of articles published in English or Spanish, up to January 2016. The search was made with the following MeSH terms: Diabetes, Mellitus, Type 2, Obesity. The inclusion criteria were: to describe in the title or summary pharmacology information of the peptide 1 receptor agonists and access to the full text. We excluded articles without any relation to the objectives of the review and articles without information on the pharmacology of AR-GLP1 agonists.

The identified articles were independently reviewed by two investigators. Considering the CONSORT checklist for clinical trials, the titles and abstracts of all the publications 
GLP1 drugs impact differently the components of the disglycemia according to their half-life: the long-acting ones produce changes in fasting blood glucose levels with minimal or no impact on postprandial blood glucose levels; while short-acting ones have a predominant effect on the postprandial glycemia. identified were reviewed, to decide their eligibility. Selected articles were analyzed jointly, and, by consensus, their inclusion was defined or not.

\section{Generalities}

The human GLP-1 receptor is a receptor coupled to G proteins, composed of 463 amino acids (). GLP-1 stimulates adenylate cyclase and phospholipase $C$ and, subsequently, activation of protein kinase $A(P K A)$ and protein kinase $C$ (PKC) that induce the proliferation of beta cells; in addition to increasing free calcium $\mathrm{Ca} 2+$ in pancreatic islets and cell lines ().

To stimulate insulin secretion, GLP-1 has a synergistic action with glucose through mechanisms that involve the closure of potassium channels $(K+)$ sensitive to ATP, resulting in depolarization of the cell membrane and increase of the intracellular $\mathrm{Ca} 2+$ levels. The insulinotropic effects of GLP-1 are dependent on plasma glucose concentrations ( $\underline{9})$.

The AR-GLP1 drugs impact differently the components of the dyusglycemia according to their half-life: the long-acting ones produce changes in fasting blood glucose levels with minimal or no impact on postprandial blood glucose levels; while short-acting ones have a predominant effect on the postprandial glycemia.

\section{Exenatide}

It is a synthetic analogue of exendin-4 obtained initially from saliva the Heloderma suspectum or Gila monster (11). It is composed of a chain of 39 amino acids of which $53 \%$ share with human GLP-1 (12); Average life is from is 1.5 to two hours, with a duration of action of six to eight hours after of a subcutaneous injection; its administration must be twice a day (13) and it is undetectable in blood after 15 hours of administration (12).

A dose of $10 \mu \mathrm{g}$ twice a day reduces glycosylated $\mathrm{A}$ hemoglobin ( $\mathrm{HbA} 1 \mathrm{c}$ ) between $0.8-1.5 \%$ (14). As monotherapy achieves a reduction in weight of $3 \mathrm{~kg}$ at 24 weeks of treatment. In uncontrolled type 2 diabetic patients with metformin or sulfonylureas, the addition of exenatide for a period of 3 to 18 months induces a weight reduction of 1.6 to $5.3 \mathrm{~kg}$. The most frequent adverse effects associated are: nausea (36-45\%), diarrhea (12 - 16\%), upper respiratory pathway infection (10 - 14\%\%), vomiting (11 - 12\%), dizziness (4 - 9\%), sinusitis (5-6\%), hypoglycemia (5\%) and back pain (3-6\%) for doses of 5 and $10 \mu \mathrm{g}(\underline{15})$.

\section{Exenatide with long-acting release (LAR)}

It was the first one with a weekly dosage, it contains the original active principle of exenatide encapsulated in $0.06 \mathrm{~mm}$ diameter microspheres (16). It has a initial release period around the second week, followed by a gradual release that generates a second peak around 6-7 weeks; after this time the average plasma concentration is approximately $300 \mathrm{pg} / \mathrm{mL}$ and is maintained at weekly dose intervals (17).

Taylor et al. in a two-year follow-up study, observed that LAR exenatide is well tolerated, in addition to having a $\mathrm{HbA} 1 \mathrm{c}$ reduction of $1.71 \pm 0.08 \%$, the change in fasting plasma glucose level is $-40.1 \mathrm{mg} / \mathrm{dL}$ and the weight reduction is from 1.58 to 3.64 $\mathrm{kg}(18)$. The most frequent adverse events in doses of $2 \mathrm{mg}$ weekly were: upper respiratory tract infection (12.5\%), diarrhea (8.6\%), nausea (7\%); vomit (6.3\%) and no major hypoglycemia is reported $(\underline{19}, \underline{20})$. 
Liraglutide has a significant reduction in blood glucose with a low incidence of hypoglycaemia, a HbA1c reduction between $0.8-1.5 \%$, decrease in pre-prandial glycemia up to $39 \mathrm{mg} / \mathrm{dL}$ and induction of weight reduction from 2 to $3 \mathrm{~kg}$ when compared with placebo.

\section{Albiglutide}

It is composed of the fusion of two sequences of 30 amino acids of human GLP-1 and recombinant human albumin (21). Presents substitution of the amino acid alanine in the second position for glycine, which is where the hydrolysis is carried out by of the enzyme DPP-4. This modification confers resistance to degradation; Besides, the fusion of amino acid sequences to human albumin prolongs its average life about 5-8 days, facilitating administration once a week $(\underline{22}, \underline{23})$.

In the study by Rosenstock et al. after 16 weeks of treatment is documented a decrease of $\mathrm{HbA} 1 \mathrm{c}$ in $-0.87,-0.79$, and $-0.87 \%$ for $30 \mathrm{mg}$ weekly, $50 \mathrm{mg}$ bi-weekly, and $100 \mathrm{mg}$ monthly, respectively; the observed weight decrease was from $-1.1 \mathrm{~kg}$ to $-1.7 \mathrm{~kg}$. Most frequent adverse reactions are: nausea (14.3 - 54\%), diarrhea (14.3 - 20.6\%), vomiting (8.6 - 41.2\%), abdominal pain (3.0 - 5.9\%), headache (11.4\%) - 23.5\%), dizziness (5.7 $14.3 \%)$, hyperglycemia (5.7 - 17.1\%), hypoglycemia (2.9 - 3.1\%), nasopharyngitis (5.7 $-11.4 \%)$. There is a dependent dose relationship regarding gastrointestinal reactions, the percentage of at least one adverse event was found between $68.6 \%$ and $85.3 \%$ (24).

Weissman et al. in the Harmony 4 Study report a decrease in $\mathrm{HbA} 1 \mathrm{c}$ of $0.66 \%$ and a decrease of $1.06 \pm 3.80 \mathrm{~kg}$ after 52 weeks of treatment with a dose of $30 \mathrm{mg}$ weekly (25).

\section{Liraglutide}

Long-acting AR-GLP1 shares $96 \%$ structural similarity with human GLP-1. It was obtained by replacing the amino acid lysine at position 34 with arginine at position $26(\underline{26})$. It contains a side chain of $\mathrm{C} 16$ fatty acid that allows to prolong the duration of its action more than 24 hours; this is achieved through the reversible binding to albumin, the increase in stability through the formation of the heptameter mediated by the fatty acid chain, aggregation at the injection site and lower susceptibility to degradation by DPP -4 (26.27). The pharmacokinetics of liraglutide allow its administration once a day, with an average life time of 11-15 hours (27).

The series of papers called "Effect of liraglutide and action on diabetes" (LEAD) $(\underline{28}, \underline{29})$ show that Liraglutide has a significant reduction in blood glucose with a low incidence of hypoglycaemia, a $\mathrm{HbA} 1 \mathrm{c}$ reduction between $0.8-1.5 \%$, decrease in pre-prandial glycemia up to $39 \mathrm{mg} / \mathrm{dL}$ and induction of weight reduction from 2 to $3 \mathrm{~kg}$ when compared with placebo. Other clinical trials like LEAD 2 (30) reports frequent gastrointestinal disorders such as nausea (11-19\%), vomiting (5-7\%\%) and diarrhea $(10,8-15 \% \%)$ as adverse events compared to treatment with glimepiride.

Liraglutide is administered as subcutaneous injection of $0.6 \mathrm{mg}$ as a dose of starting during the first week with titration to $1.2 \mathrm{mg}$ the following week and, if it is well tolerated, the dose can be increased up to $1.8 \mathrm{mg} /$ day (31).

\section{Lixisenatide}

It is a synthetic analog of exendin-4 in which six residues of the lysine amino acid have been added to the amidated terminal chain and the proline amino acid has been removed from its terminal chain. These modifications result in a life average of approximately three hours in humans (32).

In patients with renal insufficiency its clearance is reduced by approximately $30 \%$ (glomerular filtration rate $<30 \mathrm{mg} / \mathrm{dL}$ ), so adjustment of the dose in this population is required (33). In the early phase it can restore the insulin response to intravenous glucose, decrease glucagon secretion, improve systemic glucose disposal and delay gastric emptying (34). 
Current evidence suggests AR-GPL1 as a group of drugs that present an acceptable pharmacodynamic profile, significant effects in the reduction of glycaemia, inhibition of gastric emptying and discrete differences are observed regarding changes in weight.
Its application once a day (20 $\mu \mathrm{g}$ dose) in patients poorly controlled with metformin demonstrates improvement in the efficacy and tolerability ratio (35). Clinical trials such as GetGoal $(\underline{33}, \underline{36})$ show a predominant effect on postprandial glycemia with $75 \%$ reduction of excursions in standard food tests compared with placebo. This effect is expected since lixisenatide reduces gastric emptying and with an impact on body weight with reductions of 1 to $3 \mathrm{~kg}$ in doses of $20 \mathrm{mg} /$ day. Most frequent adverse events are gastrointestinal $(\underline{37}-\underline{40})$.

\section{Conclusions}

The improvement of glycemic control and weight loss have become one of the most important objectives for new therapies in diabetes. Current evidence suggests AR-GPL1 as a group of drugs that present an acceptable pharmacodynamic profile, significant effects in the reduction of glycaemia, inhibition of gastric emptying and discrete differences are observed regarding changes in weight. Its use in obesity requires the evaluation and approval of doses for this indication. Studies are still needed to assess their long-term safety.

\section{Acknowledgments}

To Carolina Prieto Saldarriaga and Carlos Esteban Builes Montaño from the Endocrinology section of the Hospital Pablo Tobón Uribe for the manuscript revision.

\section{Conflicts of interest}

None reported by the authors.

\section{Bibliography}

1. Farag YMK, Gaballa MR. Diabesity: an overview of a rising epidemic. Nephrol Dial Transplant. 2011;26(1):28-35.

2. Knop FK, Aaboe K, Vilsbøll T, Vølund A, Holst JJ, Krarup T, et al. Impaired incretin effect and fasting hyperglucagonaemia characterizing type 2 diabetic subjects are early signs of dysmetabolism in obesity. Diabetes Obes Metab. 2012;14(6):500-510.

3. Nauck MA, Homberger E, Siegel EG, Allen RC, Eaton RP, Ebert R, et al. Incretin effects of increasing glucose loads in man calculated from venous insulin and C-peptide responses. J Clin Endocrinol Metab. 1986;63(2):492-498.

4. Bastarrachea RA, Montero JC, Saavedra-Gajardo I, Cerda-Flores R, Machado-Domínguez A, Comuzzie AG. Molecular targets for new drug discovery to treat type 2 diabetes and obesity. Rev Médica Chile. 2008;136(1):107-117.

5. Drucker DJ, Nauck MA. The incretin system: glucagon-like peptide-1 receptor agonists and dipeptidyl peptidase-4 inhibitors in type 2 diabetes. The Lancet. 2006;368(9548):1696-1705.

6. Inzucchi SE, Bergenstal RM, Buse JB, Diamant M, Ferrannini E, Nauck M, et al. Management of hyperglycemia in Type 2 Diabetes, 2015: A patient-centered approach: update to a position statement of the American Diabetes Association and the European Association for the Study of Diabetes. Diabetes Care. 1 de enero de 2015;38(1):140-9.

7. Holst JJ, Burcelin R, Nathanson E. Neuroprotective properties of GLP-1: theoretical and practical applications. Curr Med Res Opin. 2011;27(3):547-558. 
8. Hansotia T, Drucker DJ. GIP and GLP-1 as incretin hormones: lessons from single and double incretin receptor knockout mice. Regul Pept. 2005;128(2):125-134.

9. MacDonald PE, El-kholy W, Riedel MJ, Salapatek AMF, Light PE, Wheeler MB. The Multiple Actions of GLP-1 on the process of glucose-stimulated insulin secretion. Diabetes. 2002;51(Suppl 3): 434-442.

10. Fineman M s., Cirincione B b., Maggs D, Diamant M. GLP-1 based therapies: differential effects on fasting and postprandial glucose. Diabetes Obes Metab. 2012;14(8):675-88.

11. Bhavsar S, Mudaliar S, Cherrington A. Evolution of Exenatide as a diabetes therapeutic. Curr Diabetes Rev. 2013;9(2):161-193.

12. Folli $f$, Mendoza RG. Potential use of exenatide for the treatment of obesity. Expert opin investig drugs. 2011;20(12):1717-1722.

13. Ahrén B. GLP-1 for type 2 diabetes. Exp Cell Res. 2011;317(9):1239-1245.

14. Kendall DM, Riddle MC, Rosenstock J, Zhuang D, Kim DD, Fineman MS, et al. Effects of exenatide (exendin-4) on glycemic control over 30 weeks in patients with type 2 diabetes treated with metformin and a sulfonylurea. Diabetes Care. 2005;28(5):10831091.

15. DeFronzo RA, Ratner RE, Han J, Kim DD, Fineman MS, Baron AD. Effects of exenatide (exendin-4) on glycemic control and weight over 30 weeks in metformin-treated patients with type 2 diabetes. Diabetes Care. 2005;28(5):1092-1100.

16. Mann KV, Raskin P. Exenatide extended-release: a once weekly treatment for patients with type 2 diabetes. Diabetes Metab Syndr Obes. 2014;7:229-239.

17. Cai Y, Wei L, Ma L, Huang X, Tao A, Liu Z, et al. Long-acting preparations of exenatide. Drug Des Devel Ther. 2013;7:963-970.

18. Taylor K, Gurney K, Han J, Pencek R, Walsh B, Trautmann M. Exenatide once weekly treatment maintained improvements in glycemic control and weight loss over 2 years. BMC Endocr Disord. 2011;11:9.

19. Drucker DJ, Buse JB, Taylor K, Kendall DM, Trautmann M, Zhuang D, et al. Exenatide once weekly versus twice daily for the treatment of type 2 diabetes: a randomised, open-label, non-inferiority study. Lancet Lond Engl. 2008;372(9645):1240-50.

20. Buse JB, Drucker DJ, Taylor KL, Kim T, Walsh B, Hu H, et al. DURATION-1: Exenatide once weekly produces sustained glycemic control and weight loss over 52 weeks. Diabetes Care. 2010;33(6):1255-1261.

21. Baggio LL, Huang Q, Brown TJ, Drucker DJ. A recombinant human Glucagon-Like Peptide (GLP)-1-Albumin Protein (Albugon) mimics peptidergic activation of GLP-1 Receptor-Dependent pathways coupled with satiety, gastrointestinal motility, and glucose homeostasis. Diabetes. 2004;53(9):2492-2500. 
22. Tomkin GH. Albiglutide, an albumin-based fusion of glucagon-like peptide 1 for the potential treatment of type 2 diabetes. Curr Opin Mol Ther. 2009;11(5):579-588.

23. Meier JJ. GLP-1 receptor agonists for individualized treatment of type 2 diabetes mellitus. Nat Rev Endocrinol. 2012;8(12):728-742.

24. Rosenstock J, Reusch J, Bush M, Yang F, Stewart M. Potential of Albiglutide, a long-acting GLP-1 receptor agonist, in Type 2 Diabetes. Diabetes Care. 2009;32(10):1880-1886.

25. Weissman PN, Carr MC, Ye J, Cirkel DT, Stewart M, Perry C, et al. Harmony 4: randomised clinical trial comparing once-weekly albiglutide and insulin glargine in patients with type 2 diabetes inadequately controlled with metformin with or without sulfonylurea. Diabetología. 2014; 57(12):2475-2484

26. Knudsen LB, Nielsen PF, Huusfeldt PO, Johansen NL, Madsen K, Pedersen FZ, et al. Potent derivatives of glucagon-like peptide-1 with pharmacokinetic properties suitable for once daily administration. J Med Chem. 2000;43(9):1664-1669.

27. Russelljones D. Molecular, pharmacological and clinical aspects of liraglutide, a once-daily human GLP-1 analogue. Mol Cell Endocrinol. 2009;297(1-2):137-140.

28. Buse JB, Rosenstock J, Sesti G, Schmidt WE, Montanya E, Brett JH, et al. Liraglutide once a day versus exenatide twice a day for type 2 diabetes: a 26-week randomised, parallel-group, multinational, open-label trial (LEAD-6). The Lancet. 2009:374(9683):39-47.

29. Buse JB, Sesti G, Schmidt WE, Montanya E, Chang C-T, Xu Y, et al. Switching to once-daily Liraglutide from twice-daily Exenatide further improves glycemic control in patients with type 2 Diabetes using oral agents. Diabetes Care. 2010;33(6):1300-1303.

30. Nauck M, Frid A, Hermansen K, Shah NS, Tankova T, Mitha IH, et al. Efficacy and safety comparison of Liraglutide, Glimepiride, and placebo, All in combination with Metformin, in Type 2 Diabetes The LEAD (Liraglutide Effect and Action in Diabetes)-2 study. Diabetes Care. 2009;32(1):84-90.

31. Garber AJ. Long-Acting Glucagon-Like Peptide 1 receptor agonists: A review of their efficacy and tolerability. Diabetes Care. 2011;34(Suppl 2):279-284.

32. Morsink LM, Smits MM, Diamant M. Advances in pharmacologic therapies for type 2 diabetes. Curr Atheroscler Rep. 2013;15(2):302.

33. Fonseca VA, Alvarado-Ruiz R, Raccah D, Boka G, Miossec P, Gerich JE. Efficacy and Safety of the Once-Daily GLP-1 Receptor Agonist Lixisenatide in monotherapy a randomized, double-blind, placebo-controlled trial in patients with type 2 diabetes (GetGoal-Mono). Diabetes Care. 2012;35(6):1225-1231.

34. Bolli GB, Owens DR. Lixisenatide, a novel GLP-1 receptor agonist: efficacy, safety and clinical implications for type 2 diabetes mellitus. Diabetes Obes Metab. 2014;16(7):588-601. 
35. Lorenz M, Evers A, Wagner M. Recent progress and future options in the development of GLP-1 receptor agonists for the treatment of diabesity. Bioorg Med Chem Lett. 2013;23(14):4011-4018.

36. Riddle MC, Forst T, Aronson R, Sauque-Reyna L, Souhami E, Silvestre L, et al. Adding Once-Daily Lixisenatide for Type 2 Diabetes inadequately controlled with newly initiated and continuously titrated basal insulin Glargine A 24week, randomized, placebo-controlled study (GetGoal-Duo 1). Diabetes Care. 2013;36(9):2497-2503.

37. Ratner RE, Rosenstock J, Boka G, on behalf of the DRI6012 Study Investigators. Dose-dependent effects of the once-daily GLP-1 receptor agonist lixisenatide in patients with Type 2 diabetes inadequately controlled with metformin: a randomized, double-blind, placebo-controlled trial. Diabet Med. 2010;27(9):1024-1032.

38. Seino Y, Ikeda Y, Niemoeller E, Watanabe D, Takagi H, Yabe D, et al. Efficacy and safety of Lixisenatide in Japanese patients with Type 2 Diabetes insufficiently controlled with basal Insulin \pm Sulfonylurea: A subanalysis of the GetGoal-L-Asia Study. Horm Metab Res Horm Stoffwechselforschung Horm Metab. 2015;47(12):895-900.

39. Seino Y, Yabe D, Takami A, Niemoeller E, Takagi H. Long-term safety of once-daily lixisenatide in Japanese patients with type 2. 2015;29(8):1304-1309.

40. Porcellati F, Lucidi P, Bolli GB, Fanelli CG. GLP-1 RAs as compared to prandial insulin after failure of basal insulin in type 2 diabetes: lessons from the $4 \mathrm{~B}$ and Get-Goal DUO 2 trials. Diabetes Metab. 2015:41(6 Suppl 1):6S16-16S20 